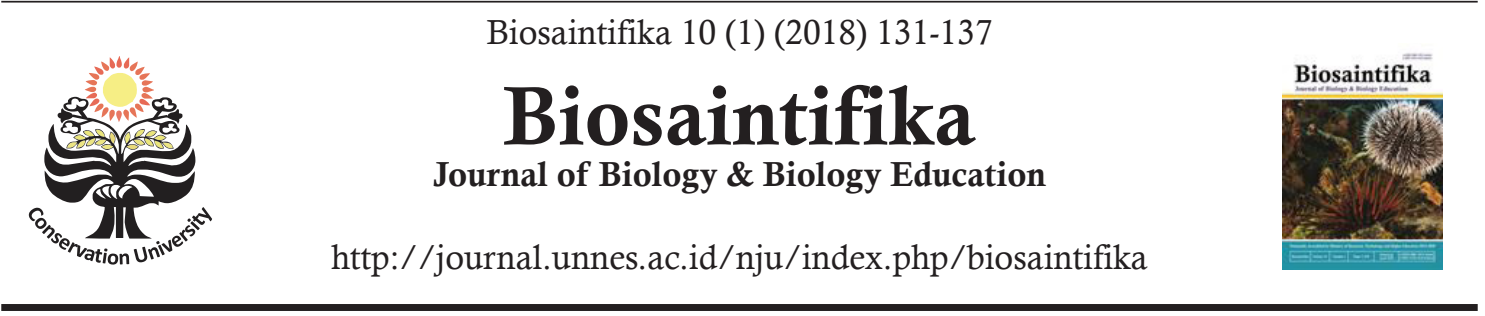

\title{
The Structural Resistance's Anatomy of Sweet Potato Leaves to Fungal Pathogen Sphaceloma batatas
}

\author{
${ }^{\square}$ Siti Samiyarsih, Juwarno, Juni Safitri Muljowati
}

DOI: 10.15294/biosaintifika.v10i1.12116

Faculty of Biology, Universitas Jenderal Soedirman, Indonesia

\section{History Article}

Received 21 November 2017 Approved 13 February 2018

Published 30 April 2018

\section{Keywords}

Leaf anatomy; Structural resistance; Scurvy; Sweet potato

\begin{abstract}
Anatomical characters can be used as instructions to the structural resistance of plants to pathogen attack. Various pathogens attack sweet potato plants, such as the Sphaceloma batatas fungus that causes scurvy disease (scab). The aims of this research to test the structural resistance of sweet potato plants based on leaf anatomical character and intensity of disease attack due to the inoculated of $S$. batatas. The research was conducted from June to November 2016, using the Completely Randomized Design Experimental (RAL) method with a factorial pattern. The first factor was ten sweet potato cultivars and the second factor was the inoculum of $S$. batatas fungus each treatment with five replications. The character of leaf anatomy observed was thick of cuticle, thick of mesophyll, size and number of stomata and number of trichomes per $1 \mathrm{~mm} 2$ leaf area. Based on the research result, it was concluded that the inoculation of the fungus of $S$. batatas caused the decrease of stomata length and width on ten sweet potato cultivars. The highest intensity of disease attack was $14.33 \%$ and correlated with stomata length $(r=0.49)$. The anatomical structural resistance to scurvy can be used as a basis for determining crosses for obtaining superior sweet potato cultivars. The benefit of the research is to advise the community to cultivate sweet potatoes that have structural resistance to scurvy, such as cuticle and thick mesophyll, high trichomata density.
\end{abstract}

\section{How to Cite}

Samiyarsih, S., Juwarno, J., \& Muljowati, J. S. (2018). The Structural Resistance's Anatomy of Sweet Potato Leaves to Fungal Pathogen Sphaceloma batatas. Biosaintifika: Journal of Biology \& Biology Education, 10(1), 131-137.

(C) 2018 Universitas Negeri Semarang
Correspondence Author:

J1. Dr. Soeparno No. 63 Purwokerto 53122

E-mail: asih.fbio@gmail.com
p-ISSN 2085-191X e-ISSN 2338-7610 


\section{INTRODUCTION}

The anatomical character is related to the structural resistance of the plant (Zarkova \& Koleva-valkova 2014; Rodrigues et al. 2015), states that plants infected with pathogens can cause morphological and anatomical changes. Anatomy contributes to species identification and quality control of plant product (Custodio et al. 2013). Common anatomical characters used are the thickness of the epidermis, cuticle thickness, leaf mesophyll thickness, stomata size and density of stomata and trichomes in plants (Kumar et al. 2012).

Plant resistance to pathogens is determined by genetic factors, and in some of its expressions is influenced by the environment and host interactions with the pathogen. Structural resistance has a role to the penetration of pathogens, as the opening of stomata guard cells is thought to be more important than the size and width of stomatal guard cell (Lawson \& Blatt 2014). Cook (1990) added that stomata density could be an indicator of plant resistance to a disease, the higher the density of stomata in the leaves, the penetration and pathogen infection to leaf tissue will decrease further. Rokhana et al. (2011) in the research reported that the resistance of chili genotypes to Begomovims causing yellow curling leaves is associated with anatomical characters, i.e., trichomes density and palisade composition in leaf mesophyll.

Sweet potato can be utilized as alternative foodstuff, besides rice and corn (Rahmiana et al. 2015). The low productivity of sweet potato is strongly influenced by various factors, such as pathogen attack. One of the pathogens that attack the sweet potato plant is Sphacheloma batatas that cause scab disease (scab). The effects are caused by scurcy can decrease result production of local sweet potatoes (Windiantini et al. 2015). The scurvy disease can infect sweet potato plants starting at 14 days. This resulted in a decreased production of sweet potato tubers ranged from $50-100 \%$ on the intensity of severe scurvy disease (Suratmaja, 2011). Genetic information is also needed to find out the genes associated with the resistance of scurvy (Ngailo et al., 2013). According to Roosda et al. (2013) that environmental factors can affect the changes in sweet potato resistance to scurvy. Cultivars that had been resistant can be turned to be resistant due to the fungal attack of skin scabies. Also, the incubation period also affects the emergence of symptoms of the scurvy disease.

Research on the structural resistance of sweet potato leaf anatomy that is resistant to leaf scurvy by $S$. batatas fungus and how the intensity of scab disease in sweet potato has not been studied. This research aims to examine the anatomical structural resistance of 10 sweet potato cultivars based on the leaf anatomical character and to know the intensity of leaf scurvy after being inoculated with $S$. batatas fungus. The benefit of the research is to advise the community to cultivate sweet potatoes that have structural resistance to scurvy, such as cuticle and thick mesophyll, high trichomata density.

\section{METHODS}

The research used the experimental method with Completely Randomized Design (RAL) with the factorial pattern. Factor I is 10 sweet potato cultivars, consisting of 7 resistant cultivars namely Borobudur, Cilembu, Cangkuang, Kidal, Sari, Solosa and Ungu Tua; 3 less resistant cultivars namely Antin, Beta and Sukuh), Factor II was treated inoculum (I1) of $S$. batatas fungus and without inoculum treatment (I0), each treatment with 5 replications.

Parameters observed included leaf cuticle thickness, mesophyll thickness, density and stomata size, trichomes density and intensity of the scurvy attack. Observation of the intensity of scabies was done by observing all the leaves on each plant. The observations were made on the leaves of the sweet potatoes after symptoms of attack began to appear. The procedures are explained as follow.

\section{Preparation of media and planting}

Soil media sterilized, then mixed with manure and inserted into polybags size $15 \mathrm{~kg}$. Sweet potato seeds were from 10 cultivars, namely Antin, Beta, Borobudur, Cangkuang, Cilembu, Kidal, Sari, Solosa, Sukuh and Ungu Tua, planted in polybags, each with 5 replications.

\section{Inoculation of fungal pathogen Sphaeloma batatas}

After two weeks, the plants were inoculated by spraying the suspension of $S$. batatas fungus on the lower surface of sweet potato leaves with spore density of $5.6 \times 106$ spores $/ \mathrm{ml}$. Inoculation treatment of fungi was done in the afternoon, then the plant was covered with plastic.

\section{Observation and collection of research data}

Observation of leaf anatomical character and disease intensity was performed after 14 days of inoculation of S.batatas fungus or after an in- 
cubation period of pathogenic fungi into plant tissue. To observe the anatomical character of sweet potato leaves, preparation of anatomical blade used paraffin method (embedding), staining with $1 \%$ safranin in $70 \%$ alcohol (Samiyarsih et al., 2016).

\section{Method of Analysis}

The data obtained were analyzed with the Analysis of Variance (ANOVA) with 95\% and $99 \%$ confidence level, data analysis continued with the Least Significant Difference Test (Fisher's LSD) 5\%.

\section{RESULTS AND DISCUSSION}

\section{The anatomical character of leaves of 10 sweet potato cultivars.}

The ten observed potato cultivars had the same anatomical leaf structure; differences were found in various anatomical characters including cell number and sizes. The observations on the anatomical character of leaves of 10 sweet potato cultivars, revealed that the thickest cuticle thickness was found in Cilembu cultivar sweet potato, which is $4.60 \mu \mathrm{m}$ and the thinnest was found in Antin and Sukuh cultivars, i.e. $3.00 \mu \mathrm{m}$ (Table 1). Based on the result of variance analysis on the thickness of sweet potato leaf cuticle, it was found that the treatment of inoculation of S.batatas fungus had no significant effect on the cuticle thickness $(p>0.05)$. The infected leaf cuticle of the disease will be thickened as an adaptation response to the unfavorable environment resulting from pests and diseases. The presence of thicker leaf cuticle in sweet potato leaf that is resistant to leaf scurvy disease allegedly can inhibit the penetration or infection of a pathogen into the tissue. Yeats \& Rose (2013) stated that cuticle thickness in a plant is affected by the habitat or environmental conditions of the growth of the plant. Cuticle thickness is the nature of structural resistance to pathogen attack into the plant body. Pantilu et al. (2012) added that each plant cultivar has a different cuticle thickness. Thick cuticles in a plant have relatively better structural resistance than plants with thin cuticles.

The mesophyll thickness observation in Cilembu cultivar has the thickest mesophyll that is $168,00 \mu \mathrm{m}$, while the Sukuh cultivar has the thickest mesophyll thickness that is $84,00 \mu \mathrm{m}$ (Table 1). Anatomical observations can be seen through mesophyll tissue. The mesophyll tissue infected by the pathogen undergoes a larger form of change due to tissue swelling by pathogen activity. Leaves infected with pathogens experience faster cell division. Palisade tissue will changesize and deformation, so the tissue size becomes thicker. The result of analysis of variance (Anova) to the thickness of mesophyll obtained that inoculation treatment of $S$. batatas fungal has an effect on thick of mesophyll ( $p<0.01)$. The difference in mesophyll thickness in sweet potatoes inoculated by $S$. batatas was by the statement of Giordani et al. (2012) and Jeniria et al. (2015) that the mesophyll tissue infected with a disease has a larger size. (Zarkova \& Koleva-valkova 2014) adds a histological change in the leaves of Prunus persica (L.) infected by Taphrina deformans, an increased mesophyll tissue thickness and loss of differentiation in the palisade parenchyma and spongy parenchyma. The place of parasite penetration into the leaf is marked by the necrosis of epidermis and mesophyll to the extent that necrotized tissue falls out from the plant (Biruliova et al. 2013). The observations on the anatomical character of 10 sweet potato cultivars are presented in Table 1.

Based on observations on the density and size of stomata (Table 1) showed varying results in resistant cultivars and less resistance to leaf scurvy disease. The highest number and size of stomata were found in 2 less resistant cultivars, i.e. Beta and Sukuh cultivars ranged from 15.60 - 18.20 per $\mathrm{mm}^{2}$ of leaf epidermis, with stomata length between $23.00-28.00 \mu \mathrm{m}$ and stomata width between $4.00-4.50 \mu \mathrm{m}$. The result of analysis of variance (Anova) to stomata length size $(p<0.01)$ and stomata width $(p<0.01)$ obtained that inoculation treatment of $S$. batatas fungal gave significant influence to the length and width of sweet potato stomata. Based on the Least Significant Difference Test (Fisher's LSD) 5\%, it was found that the treatment of inoculation of $S$. $b a$ tatas fungal caused a decrease of stomata length and width. The stomata size difference inoculated by $S$. batatas was suspected of penetration and infection of $S$. batatas. An open stomata guard cell may cause active penetration of a sprout tube or zoospores. At the time of penetration, the sprouts can enter the tissue through the stomata. Stomata will minimize its size as an adaptation response to penetrate $S$. batatas inhibited. Therefore, the stomata guard cells which opening narrower allegedly will be more resistant to pathogen penetration. Lestari (2006) stated that stomata would minimize its size to inhibit the pathogenic sprout tube from entering the tissues. Stomata is responsive to unfavorable environmental changes (Kounwenberg et al. 2004). Saleh (2010) state that fungal infection of leaf spot can occur through both sides of the leaf using penetration directly through the epidermal tissue cells or the mouth 
Table 1. Average anatomical character of 10 leaves of sweet potato cultivars

\begin{tabular}{ccccccc}
\hline $\begin{array}{c}\text { Cultivars } \\
\text { Sweet } \\
\text { Potato }\end{array}$ & $\begin{array}{c}\text { Thickness } \\
\text { Cuticle } \\
(\mu \mathrm{m})\end{array}$ & $\begin{array}{c}\text { Thickness of } \\
\text { Mesophyll } \\
(\mu \mathrm{m})\end{array}$ & $\begin{array}{c}\text { Number } \\
\text { of Stomata } \\
\left(\mathrm{mm}^{2}\right)\end{array}$ & $\begin{array}{c}\text { Length Sto- } \\
\text { mata } \\
(\mu \mathrm{m})\end{array}$ & $\begin{array}{c}\text { Stomata } \\
\text { Width } \\
(\mu \mathrm{m})\end{array}$ & $\begin{array}{c}\text { Number of } \\
\text { Trichomes } \\
\left(\mathrm{mm}^{2}\right)\end{array}$ \\
\hline Antin & $3.00 \pm 0.68$ & $125.50 \pm 10.37$ & $7.80 \pm 1.3$ & $25.10 \pm 3.26$ & $4.50 \pm 0.68$ & $1.40 \pm 0.5$ \\
Beta & $3.15 \pm 0.54$ & $95.50 \pm 13.28$ & $18.20 \pm 1.9$ & $28.00 \pm 2.09$ & $4.50 \pm 1.04$ & $1.40 \pm 0.5$ \\
Borobudur & $3.25 \pm 0.68$ & $131.00 \pm 7.16$ & $13.60 \pm 1.8$ & $29.00 \pm 2.85$ & $4.25 \pm 1.12$ & $1.40 \pm 0.5$ \\
Cangkuang & $3.40 \pm 0.68$ & $134.50 \pm 6.69$ & $13.20 \pm 2.4$ & $26.50 \pm 2.85$ & $4.00 \pm 1.05$ & $2.40 \pm 0.4$ \\
Cilembu & $4.60 \pm 0.68$ & $168.00 \pm 13.53$ & $17.20 \pm 1.8$ & $31.00 \pm 1.37$ & $4.65 \pm 0.55$ & $1.40 \pm 0.5$ \\
Kidal & $3.50 \pm 0.87$ & $125.00 \pm$ & $11.40 \pm 1.9$ & $27.50 \pm 3.95$ & $4.15 \pm 1.12$ & $1.80 \pm 0.8$ \\
& \multicolumn{7}{c}{20.80} & & & & \\
Sari & $3.50 \pm 1.45$ & $123.00 \pm 9.94$ & $11.60 \pm 1.1$ & $27.00 \pm 2.09$ & $3.50 \pm 1.05$ & $1.40 \pm 0.4$ \\
Solosa & $3.75 \pm 0.56$ & $98.50 \pm 8.94$ & $11.60 \pm 1.1$ & $27.50 \pm 2.50$ & $3.75 \pm 0.88$ & $1.80 \pm 0.5$ \\
Sukuh & $3.00 \pm 0.68$ & $84.00 \pm 6.85$ & $15.60 \pm 2.3$ & $23.50 \pm 2.24$ & $4.00 \pm 0.68$ & $2.40 \pm 0.5$ \\
Ungu Tua & $3.25 \pm 0.68$ & $85.00 \pm 4.87$ & $13.10 \pm 2.1$ & $21.50 \pm 1.37$ & $4.00 \pm 0.68$ & $2.60 \pm 0.7$ \\
\hline
\end{tabular}

of the leaf (stomata). (Biruliova et al. 2013) adds parasite penetration into the leaf is marked by the necrosis of epidermis and mesophyll to the extent that necrotized tissue falls out from the plant.

The result of analysis of variance to density or amount of stomata showed that the inoculation treatment of $S$. batatas fungal has a very significant effect to the density or the number of stomata $(\mathrm{p}<0.01)$. The density and size of stomata become a structural resistance factor of the plant because the density and size of stomata affect the chance of penetrating the pathogen into the plant body. The results of this research were not in accordance with the results of research Haryanti (2010) which reported that in Zephyranthes rosea plant showed the pathogen treatment gave a very significant effect on the number of stomata of upper and lower leaf surface. According to Kouwenberg et al. (2004), each plant cultivar has a different stomata density. In addition, stomata density can be an indicator of plant resistance to a disease, the higher the density of stomata in the leaves, the penetration and pathogen infection to the leaf tissue will be higher (Cook, 1990).

The result of analysis of variance to density or amount of trichomata obtained that inoculation treatment of S.batatas fungal influence to density or amount of trichomata per $1 \mathrm{~mm}^{2}$ of sweet potato leaf area $(p<0.01)$. Trichomata density will increase if infected by disease as an unfortunate adaptation response to the environment, this is related to trichomata which has a function as structural resistance to disease intensity. The density of the trichomata is relatively high when it grows in an environment that is exposed to a lot of light, it is related to the function of the trichomata which can decrease the tran- spiration rate in the leaves. Pérez-Estrada et al., 2000) suggest that trichomata density is affected by seasonal changes, light intensity, and disease intensity. The cross-section of leaves of 10 sweet potato cultivars can be seen in Figure 1.
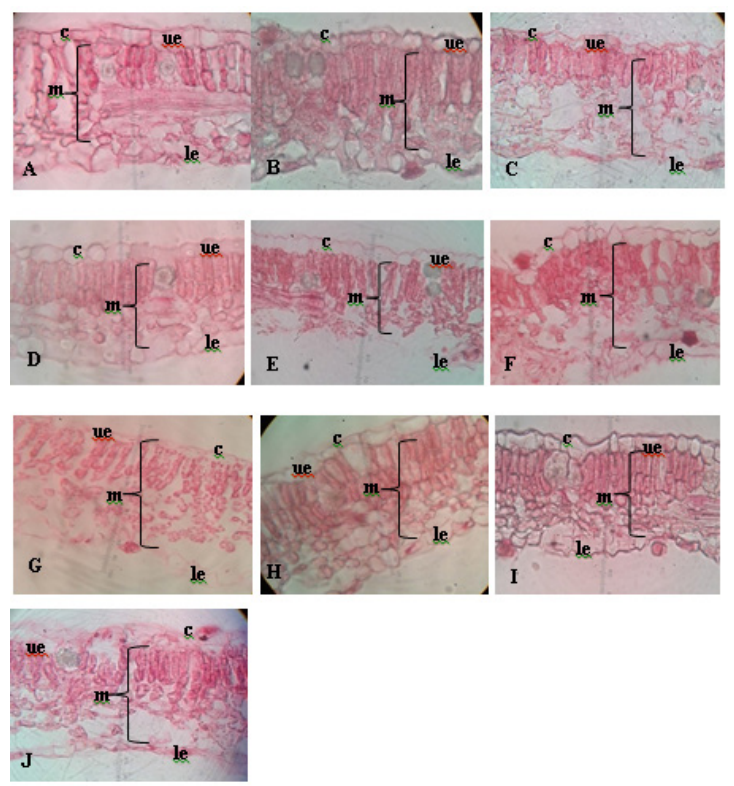

Figure 1. The cross-section of leaves ten sweet potato cultivars, 400X; Magnification.Description: A. Antin; B. Beta; C. Borobudur; D. Cangkuang; E. Cilembu; F. Kidal; G. Sari; H. Solosa; I. Sukuh; and J. Ungu Tua, c= cuticle; ue= upper epidermis; $\mathrm{m}=$ mesophyll; $1 \mathrm{e}=$ lower epidermis.

Stomata and trichomata leaves of 10 sweet potato cultivars can be seen in figure 2 below. 


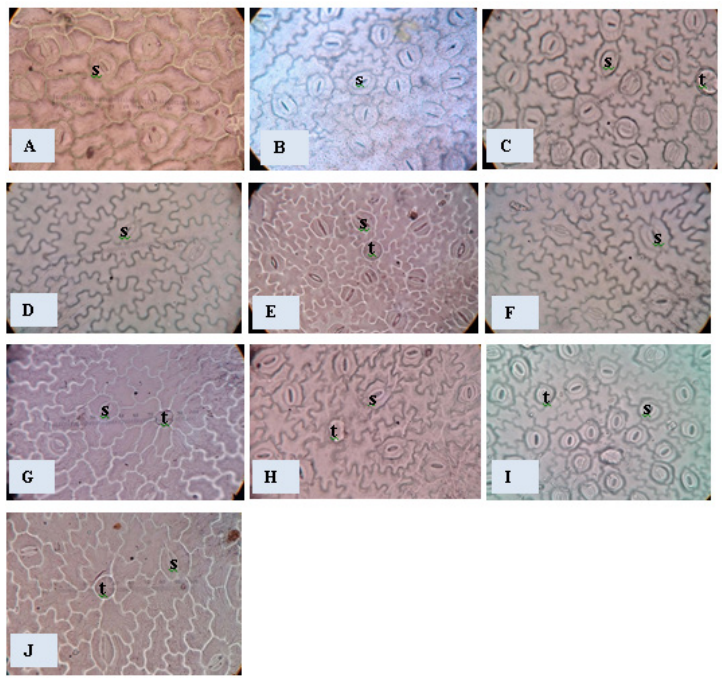

Figure 2. Stomata and trichromata leaves of 10 sweet potato cultivars, $400 \mathrm{X}$ magnification. Description: A. Antin; B. Beta; C. Borobudur; D. Cangkuang; E. Cilembu; F. Kidal; G. Sari; H. Solosa; I. Sukuh; and J. Ungu Tua, s= stomata; $\mathrm{t}=$ trichomata

\section{Intensity of The Scab Disease}

The level of disease resistance in the plant is classified into five categories. The endurance of sweet potato cultivars is based on the intensity of the disease being observed. Based on the observation of 10 sweet potato cultivars, the Borobudur cultivar has the highest intensity of disease attack, i.e. $14.33 \%$ and Kidal cultivar possesses the lowest intensity of scurvy, i.e. $5.13 \%$. The emergence of symptoms of scurvy can be seen on leaves and bone leaves. In the infected leaves yellow spots appear, then turned into brownish yellow and finally black. Spots can expand and will unite with other spots. The observations show that on observation first seven days after inoculation has not shown symptoms of scurvy. At the second observation 14 days after inoculation, symptoms of scurvy begin to be found in the cultivar of Borobudur by $14.33 \%$ and Ungu Tua cultivar by $8.79 \%$. Martanto et al. (2016) stated that the penetration of fungal scurvy on sweet potatoes occurs 12 hours after inoculation through open stomata. The cross-section of the infected bone leaves of sweet potato indicates the presence of a conidium that tears the epidermal layer. Differences in the intensity of the disease in each sweet potato cultivar allegedly influenced uredospora from $S$. batatas that can penetrate into the tissue.

Relatively high humidity causes $S$. babatas to penetrate, infect and deform in tissues. Environmental factors such as humidity at the study sites ranged between $70-86.5 \%$. According to Junita et al. (2017) the penetration of a pathogen is affected by moisture. The higher the moisture the faster the penetration of a pathogen to its host tissue. It was reported that fungal pathogen could penetrate naturally in the have leaves during the morning between the hours of 3-4 am. Humidity required this fungus ranges between $89-98 \%$ can penetrate mechanically. Rodrigues et al. (2015) added that lysis on the mesophyll were measured in seedlings of Coffea arabica cv. Mundo Novo, susceptible to Pseudomonas syringae pv. garcae, by using histological sections obtained at 10 and 20 days after inoculation.

The percentage of disease intensity (IP) values associated with plant resistance criteria for disease-causing pathogens, then ten sweet potato cultivars were classified as cultivars resistant to scurvy because they had an IP value below $25 \%$. Based on the result of correlation analysis of the anatomical character of sweet potato leaves with the intensity of disease attack, it was found that the intensity of the attack correlated with the stomata length $(\mathrm{r}=0.49)$. This is in accordance with Martanto (2010) research which states that the intensity of the attack relationship with leaf anatomy is not so strong, because the higher the intensity of the attacks value there is also a high anatomical valuae as well. Inayati and Yusnawan (2016) also reported that soybean response to leaf rust disease influenced environmental factors, namely temperature, humidity and physiological factors of the plant. The intensity of scab disease on ten sweet potato cultivars is presented in Figure 3 .

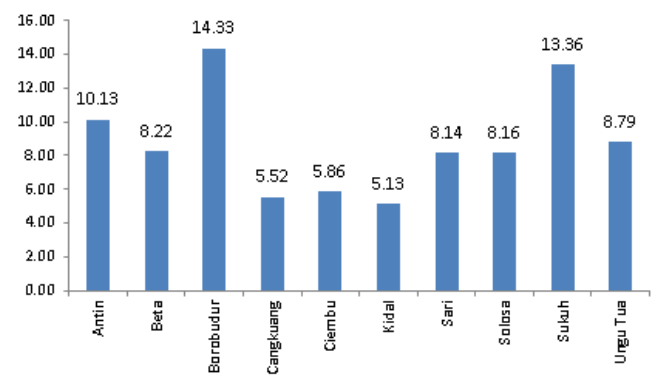

Figure 3. The intensity of scab disease (\%) on ten sweet potato cultivars

Inoculation of the S.batatas fungus causes a decrease in the length and width of the stomata in ten sweet potato cultivars. The highest intensity of disease attack on the cultivar of Borobudur is $14.33 \%$. The structural resistance anatomy of leaves to scurvy can be used as a basis for determining crosses for obtaining superior sweet pota- 
to cultivars. It is advisable to obtain higher yields recommended for culturing sweet potatoes that have structural resistance with cuticles and thick mesophyll, high trichomata densities, such as $\mathrm{Ci}$ lembu and Cangkuang cultivars.

\section{CONCLUSION}

Based on the research results, it can be concluded that the attack of the Sphaceloma batatas fungus would cause changes in anatomical structure especially the length and width of stomata. Cultivar of Borobudur was the cultivar with the highest attack intensity. The results of this study might be useful as a basis for determining the elder cultivar sweet potato resistant to the attack of $S$. batatas fungus.

\section{ACKNOWLEDGEMENT}

Acknowledgments are submitted to LPPM (Lembaga Penelitian dan Pengabdian kepada Masyarakat) Jenderal Soedirman University who had provided research funding on the Superior Research Scheme of Higher Education. Thanks to Supriyono for research implementation assistance.

\section{REFERENCES}

Biruliova, E. ;Prosiannykova I., \& Fedotova A. (2013). The rust fungus Uromyces geranii (DC.) Lev. Localization and Impact on anatomy of The host plant Geranium sanguineum L. Modern Phytomorphology. 4, 109-113.

Cook, M. (1990). Peanut Leaf Wettability and Susceptibillity to Infection by Puccinia arachidis. Journal Phytophatology. 70 (1), 826-830.

Custodio, D.L., Kolb, R.M., Faria, T.J. \& Bianchini, E. (2013). Pimenta pseudocaryophyllus (Gomes) L.R. Landrum (Myrtaceae): Stem and leaf anatomy of a medicinal plant. Ciências Biológicas e da Saúde, Londrina 34(2), 111-124

Giordani, E. Padula, G., \& Radice, S. (2013). Compared Anatomy of Young Leaves of Prunus persica (L.) Batsch with Different Degrees of Susceptibility to Taphrina deformans (Berk.) Tul. Journal of Phytophatology. 161 (1), 190-196.

Haryanti, S. (2010). Pengaruh Naungan yang Berbeda terhadap Jumlah Stomata dan Ukuran Porus Stomata Daun Zephyranthes Rosea Lindl. Buletin Anatomi dan Fisiologi. 58 (1), 41-48.

Inayati, A. \& Yusnawan, E. (2016). Characteristics of Superior Soybean Breeding Lines Tolerance to Rust (Phakopsora pachyrhizi). Biosaintifika: Journal of Biology \& Biology Education, 8(1), 4755.

Jeniria, S., Ivanka, B.S., \& Neshka, G. (2015). Ana- tomical Changes in Peach Leaves Infected by Taphrina deformans (Berk). Botany and Agricutural. 5(1), 101-106.

Junita, R., Lubis, L., Pinem, M.I \&\& Dalimunthe, C.I. (2017). The Relation of Leaf Anatomy due to the Resistance of Leaves Fall Disease in Rubber (Havea brassiliensis Muell. Arg). Jurnal Agroekoteknologi. 5(1), 160-166.

Kouwenberg, L.L.R., Kursner, W.M., \& Visscher, H. (2004). Changes in Stomata Frequences and Size During Elongation of Tanga Heterophylla. Annual of Botany, 95(1), 561-569.

Kumar, V., Kodandaramaiah, J. \& Rajan, M.V. (2012). Leaf and anatomical traits in relation to physiological characteristics in mulberry (Morus sp.) cultivars. Turk. J. Bot. 30, 683-689.

Lawson, T., \& Blatt, M.R. (2014). Stomatal Size, Speed, and Responsiveness Impact on Photosynthesis and Water Use Efficiency. Plant Physiology. 164, 1556-1570.

Lestari. L.G. 2006. Hubungan antara Kerapatan Stomata dengan Ketahanan Kekeringan pada Tanaman Padi. Jurnal Biodiversitas. 7 (1), 44-48.

Martanto, E.A. ; Tanati, A. \& Baan, S. (2016). Evaluasi Ketahanan Terhadap Penyakit Kudis Dan Produksi Beberapa Kultivar Ubi Jalar. J. .HPT Tropika. 16(1) : 35-41.

Ngailo S., Shimelis H., Sibiya J., \& Munda K. (2013). Sweet potato breeding for resistance to sweet potato virus disease and improved yield: Progress and challenges. African Journal of Agricultural Research. 8(25).pp 3202-3215.

Pantilu, L.L., Mantri, F.R., Ai, N.S., \& Pandiangan, D. (2012). Respon Morfologi dan Anatomi Kacang Kedelai (Glycine max L.) Terhadap Intensitas Cahaya yang Berbeda. Jurnal Bioslogos. 2 (2), 79-87

Perez-Estrada, L.B., Cano-Santana, Z. \& Ken-Oyama. (2000). Variation in leaf trichomes of Wigandia urens : environmental factor and physiological consequences. Tree Physiology. 20, 629-632.

Rahmiana, E.A., Tyasmoro, S.Y. \& Suminarti, N.E. (2015). The Effect On Vein Length Reduction And Reversal Frequency of Stem On Growth And Yield of Sweet Potato (Ipomoea batatas L.) Orange Honey Variety. Jurnal Produksi Tanaman. 3(2), 126-134.

Rodrigues, L.M.R., Queiroz-Voltan, R.B. \& Filho, O.G. (2015). Anatomical changes on coffee leaves infected by Pseudomonas syringae pv. Garcae. Summa Phytopathologica, 41(4), 256-261.

Rokhana, F., Sujiprihati, S., Syukur, Hidayat, M., \& Hendrastuti, S. (2011). Mekanisme Ketahanan Struktural Cabai Terhadap Begomovirus Penyebab Penyakit Daun Keriting Kuning (Pepper Yellow leaf curl virus). URL http://repository.ipb.ac.aid/handle/12345678/58428

Roosda, A.A., Waluyo, B., Yulia, E., Widiantini, F. \& Karuniawan, A. (2013). Identifikasi Ketahanan Ubi Jalar Lokal terhadap Penyakit Kudis sebagai Dasar Penentuan Tetua Persilangan. Prosiding Seminar Hasil Penelitian Tanaman Aneka 
Siti Samiyarsih et al. / Biosaintifika 10 (1) (2018) 131-137

Kacang dan Umbi, 649-655.

Samiyarsih S. Suparjana, T.B. \& Juwarno. (2016).

Karakter Antomi DaunTumbuhan Mangrove Akibat Pencemaran di Hutan Mangrove Kabupaten Cilacap. Biosfera: 33(1). 31-36

Saleh, N. (2010). Optimalisasi Pengendalian Terpadu Penyakit Bercak Daun dan Karat pada Kacang Tanah. Pengembangan Inovasi Pertanian, 3(4), 289-305.

Suratmaja, A.G. (2011). Evaluasi Sifat Ketahanan 16 Klon Harapan Ubi Jalar (Ipomoea batatas L.) terhadap Penyakit Kudis (Sphaceloma batatas). http//elibrary.ub.ac.id/handle/123456789/30633. Diakses 9 Oktober 2016
Widiantini F.; Yulia E. ; Roosda A.A. \& Kurniawan A. 2015. Seleksi Ketahanan Ubi Jalar Madu Genotipe F1 terhadap Penyakit Kudis (Sphaceloma batatas Saw.). Jurnal Agrikultura. 26(1) : 23-29.

Yeats, T.H. \& Rose, J.K.C. (2013). The Formation and Function of Plant Cuticles. Topical Review on Cuticle Synthesis and Function. Plant Physiology. 163, 5-20.

Zarkova, M.V., Koleva-Valkova, L.H., Semerdjeva, I.B. \& Piperkova, N.G. (2014). Anatomical Changes in Peach Leaves Infected by Taphrina deformans (Berk.) Tul. Ecologia Balkanica. 5, 101-106. 